\title{
o que dizem as crianças ribeirinhas da vila do piriá - curralinho/pa - acerca de suas práticas culturais
}

\author{
simei santos andrade ${ }^{1}$ \\ universidade federal do pará - brasil \\ magali dos reis ${ }^{2}$ \\ pontifícia universidade católica de minas gerais \\ laura maria silva araújo alves ${ }^{3}$ \\ universidade federal do pará - brasil
}

resumo

A pesquisa que ora apresentamos é um recorte de um estudo mais amplo sobre Infâncias da Amazônia, com destaque para a infância e as crianças ribeirinhas e suas práticas culturais. A investigação teve como lócus o distrito Vila do Piriá, localizado no município de Curralinho/PA, na Amazônia Marajoara. É a maior comunidade da região fora da sede do município, com um contingente de crianças, na faixa etária de 0 a 11 anos, que chega a um percentual de 38,06\% da população (IBGE, 2010); um lugar com tantos movimentos e crianças tem muito a dizer dos seus modos de vida. A Vila sente os reflexos da falta de políticas públicas direcionadas para a região, gerando, por exemplo, sérias dificuldades à população no acesso aos serviços básicos (saúde, educação, saneamento, habitação e infraestrutura), o que se traduz nos baixos índices de indicadores sociais e educacionais, com destaque para o IDH e o IDEB. Os interlocutores da pesquisa são 20 (vinte) crianças na faixa etária de 5 a 11 anos, moradoras da Vila; porém, não nos detivemos somente a elas, pois entendemos que a infância não está desatrelada da cultura ou vivências dos adultos, portanto, ouvir a unidade doméstica respaldou ainda mais nossa análise, permitindo perceber, no que diz respeito ao universo ribeirinho, que as crianças e os adultos estão intimamente ligados pelos seus modos de vida, tão particulares. O estudo teve por objetivo analisar o que falam as crianças da Vila do Piriá acerca de suas práticas culturais vivenciadas no cotidiano, numa região de água e floresta. O referencial teóricometodológico respalda-se nos Estudos Sociais da Infância, em diálogo, principalmente, com a Sociologia da Infância, mas também conta com aportes na Geografia da Infância, Antropologia da Criança e na História da Infância. A investigação foi realizada por meio de uma abordagem qualitativa, baseada numa etnografia com crianças, considerado um método eficaz para investigação dos aspectos culturais de grupos sociais específicos. As conclusões desta etapa do estudo mostram que as crianças da Vila do Piriá dominam saberes atrelados às vivências que norteiam suas práticas sociais cotidianas, como andar de canoa, nadar, pescar, caçar, apanhar açaí, colocar matapi, entre outros. Têm a capacidade de dizer do seu lugar de uma maneira simples, concreta e sensível, com a predominância da cultura oral sobre a escrita, produzindo histórias que geram multiplicidades de enfoques da cultura e do lugar. Neste ensaio serão abordadas quatro práticas culturais vivenciadas pelas crianças.

palavras-chave: práticas culturais; crianças ribeirinhas; vila do piriá - curralinho/pa.

\footnotetext{
${ }^{1}$ E-mail: simeiandrade@uol.com.br

${ }^{2}$ E-mail: magali_reis@pucminas.br

${ }^{3}$ E-mail: laura_alves@uol.com.br
} 
o que dizem as crianças ribeirinhas da vila do piriá - curralinho/pa - acerca de suas práticas culturais

\section{what ribeirinho ${ }^{4}$ children of piriá village - curralinho/pa say about their cultural practices}

abstract

The presented research focuses on a portion of a larger study on "Amazon childhood"; with emphasis on the cultural practices of ribeirinho children and their respective childhood. The chosen locale of the aforementioned research happens to be in the Piriá Village district; in Curralinho County/PA in the Marajoara Amazon region. It's the largest community in the region outside the county area; with a group of children from 0 to 11 years old that reaches the percentage of $38 ; 06 \%$ of the local population (IBGE; 2010). A place with such cultural activities and children says plenty about their lifestyle. Due to the lack of public policies; the village endures the consequences of poor accessibility to basic services such as health care; education; sanitation; housing and infrastructure; which leads to aggravating problems to the population. This is particularly evident as we see the low rates of social indicators in the Marajoara Amazon; specially for HDI and IDEB (Basic Education Development Index). The total of interviewed are 20 children from 5 to 11 years old; natives of the Village; however we haven't limited the object of study to them as we understand that childhood is not strictly isolated from the adult's cultural and personal experiences. Therefore; the listening of the families considerably strengthened our analysis; enabling us to perceive characteristic s of the Riberinho lifestyle; which entails that both children and adults are intricately connected by their peculiar lifestyles. The study had as its primary objective analyse what children from the Piria village report regarding their own cultural practices experienced throughout their daily routines in a rainforest area. The theoretical methodological reference is based on childhood social studies partnered with childhood sociology; and also with childhood geography; infant anthropology and infant history. The investigation was conducted by a qualitative approach; based on infant ethinography; which is considered an effective method for the investigation of cultural aspects of specific social groups. The conclusions of this part of the study shows that the children of Pirá village master the knowledge linked to their personal experiences that guide their social daily practices; such canoeing; fishing; hunting; grab açaí berries; to use matapi (trap for shrimps made of wood among others). They have the capacity of talking about their community in a simple; concrete and sensitive way; with the predominance of the oral tradition over the written; producing stories that generate a multitude of cultural and regional insights. This essay will address four cultural practices experienced by children..

keywords: cultural practices; ribeirinho children; piriá village - curralinho/pa.

\section{qué dicen los niños riberenõs de la villa del piriá - curralinho/pa - acerca de sus prácticas culturales}

resumen

La investigación que presentamos es un recorte de un estudio más amplio sobre Infancias de la Amazonia, con un foco especial en la infancia y los niños ribereños y sus prácticas culturales. La investigación tuvo como local el distrito Villa del Piriá, situado en el municipio de Curralinho/PA (Estado de Pará) en la Amazonia Marajoara. Ésta es la

\footnotetext{
${ }^{4}$ Ribeirinho: nomenclature given to populational group which lives by the rives, getting its sustenance through the extraction and handling of forest, river and agricultural resources in small scale, in a direct relation with nature and its cultures.
} 
mayor comunidad de la región fuera de la sede del municipio, con un contingente de niños en el grupo de edad de 0 a 11 años que llega a un porcentaje del 38;06\% de la población (IBGE; 2010). Un lugar con tantos movimientos y niños tiene mucho que decir sobre sus modos de vida. La Villa siente los reflejos de la falta de políticas públicas dirigidas a la región, generando, por ejemplo, serias dificultades a la población en el acceso a los servicios básicos (salud, educación, saneamiento, vivienda e infraestructura), lo que se traduce en los bajos índices de indicadores sociales en la Amazonia Marajoara, especialmente el IDH (Índice de Desarrollo) y el IDEB (Índice de Desarrollo de la Educación Básica). Por lo tanto, oír las unidades domésticas respaldó aún más nuestro análisis, permitiendo percibir, en lo que se refiere al universo ribereño, que los niños y los adultos están íntimamente ligados por sus modos de vida tan particulares. El estudio tuvo por objetivo analizar lo que dicen los niños de Villa del Piriá acerca de sus prácticas culturales cotidianas en una región de agua y bosque. Las referencias teóricometodológicas se respaldan en los Estudios Sociales de la Infancia, en diálogo, principalmente, con la Sociología de la Infancia. Pero también cuentan con aportes de la Geografía de la Infancia, la Antropología del Niño y la Historia de la Infancia. La investigación se realizó a partir de un enfoque cualitativo basado en una etnografía con niños por considerarse un método eficaz para la investigación de los aspectos culturales de grupos sociales específicos. Las conclusiones de esta etapa del estudio muestran que los niños de Villa del Piriá dominan saberes vinculados a las vivencias que orientan sus prácticas sociales cotidianas como pasear en canoa, pescar, cazar, cosechar açaí, poner trampas para capturar camarones, entre otros. Tienen la capacidad de hablar de su lugar de una manera sencilla, concreta y sensible con la predominancia de la cultura oral sobre la escrita, produciendo historias que generan multiplicidades de enfoques de la cultura y del lugar.

palabras claves: prácticas culturales; niños ribereños; villa del piriá - curralinho/pa. 
o que dizem as crianças ribeirinhas da vila do piriá - curralinho/pa - acerca de suas práticas culturais

o que dizem as crianças ribeirinhas da vila do piriá - curralinho/pa - acerca de suas práticas culturais

\section{introdução}

Compreender as práticas culturais no cotidiano das crianças foi o nosso desafio, na medida em que tais práticas estão envoltas em uma série de questões relacionadas à constituição da identidade, espacialidade, sensações, tempo, meio ambiente e vivências nas várias dimensões da vida do sujeito-criança do Norte do Brasil, especificamente da Amazônia Marajoara.

Essa pesquisa tem como temática "As infâncias da Amazônia", focalizada na "infância e nas crianças ribeirinhas". Objetivou analisar o que falam as crianças da Vila do Piriá - Curralinho/PA - acerca de suas práticas culturais vivenciadas no cotidiano, numa região de água e floresta. Apreender a infância amazônica é abrir possibilidades para entender a identidade do ser que "[...] cria, renova, interfere, transforma, reformula, sumariza, ou alarga sua compreensão das coisas, suas ideias, por meio do que vai dando sentido a sua existência" (LOUREIRO, 2007, p. 11).

As crianças ribeirinhas estão inseridas numa determinada realidade, numa dada cultura e num ambiente que constituem o meio e, à medida que se desenvolvem, o meio se modifica para elas e influencia na sua maneira de perceber o mundo. Nesse sentido, Vigotski (2010, p. 683) assevera que "os elementos existentes para determinar a influência do meio no desenvolvimento de sua personalidade consciente é a vivência". Percebemos que as crianças amazônidas vivenciam experiências nas mais diversas dimensões da sua vida, encontrando-se, igualmente, na Amazônia, com uma cultura de expressão singular, com características próprias marcantes na qual o impulso cultural vem da relação e movimentação com a natureza (LOUREIRO, 2000).

Analisar as práticas culturais das crianças ribeirinhas a partir do que dizem sobre si e o mundo nos leva a olhar a infância na Vila do Piriá sob um novo paradigma, o da criança que diz o que pensa, o que deseja, o que quer e o que anseia. Este exercício nos auxiliará a entender que lugar as crianças têm nesta 
cultura, as características relevantes da infância ribeirinha, as práticas culturais realizadas por elas a partir de suas vivências com a natureza, com o corpo, os sentimentos e a cultura local.

\section{percurso teórico-metodológico do estudo}

Nossa investigação desenvolveu-se através uma abordagem qualitativa, por ser esta a que melhor se aproxima do nosso objetivo de estudo - o que dizem as crianças ribeirinhas da Vila do Piriá - Curralinho (PA) - sobre suas práticas culturais. Consideramos a análise por meio desta abordagem, uma vez que ela "[...] se aprofunda no mundo dos significados" (MINAYO, 2012, p. 22) das relações humanas. Preocupa-se em compreender, interpretar o sentido do fenômeno de natureza social (GONSALVES, 2001).

O estudo expandiu-se a partir de pesquisa etnográfica, pois foi a que melhor se aplicou ao nosso campo de investigação com crianças, procurando compreender as concepções, os significados culturais (ANDRÉ, 1995), as relações que as crianças estabelecem no cotidiano com seus pares e com a natureza. Considera-se, ainda, que "[...] é um método eficaz para estudar crianças porque muitos recursos de suas interações e culturas são reproduzidos e compartilhados no presente e não podem ser obtidos facilmente por meio de entrevistas reflexivas ou questionários [...]" (CORSARO, 2011, p. 63).

Na investigação buscou-se também compreender, por meio de uma relação direta com as crianças no espaço e tempo de uma comunidade ribeirinha, de que forma se organizam como grupo social na comunidade e como constroem maneiras, saberes, competências, sentidos que são vivenciados entre elas e unidos a sua identidade enquanto grupo de crianças (ARENHART, 2016). Assim, a investigação se constituiu em um estudo com as crianças, sem deixarmos de considerar, também, ser um estudo sobre elas, na medida em que a unidade doméstica foi ouvida, além de observações e registros realizados durante a pesquisa de campo, o que nos permitiu a ampliação das análises sobre suas práticas culturais. 
o que dizem as crianças ribeirinhas da vila do piriá - curralinho/pa - acerca de suas práticas culturais

O estudo centrou-se nos Estudos Sociais da Infância, em diálogo principalmente com a Sociologia da Infância, mas também com aporte na Geografia da Infância, Antropologia da Criança e na História da Infância. Coutinho (2016) referenda que, embora existam desde o século XIX, é na contemporaneidade que o foco interdisciplinar dos Estudos Sociais da Infância e a participação de mais áreas das Ciências Sociais e Humanas se intensificam, possibilitando estudos e pesquisas em campos diversos, merecendo destaque, neste estudo, Arenhart (2016); Corsaro (2011); Kramer (2011); Loureiro (2000, 2007); Müller; Hassen (2009); Sarmento (2017); e Sousa (2014). Certamente, com esses diálogos construímos um campo com multiplicidade de vozes, o que possibilitou o entrelaçamento teórico da pesquisa. Em virtude de esta investigação estar focada na infância, partimos de questões interdisciplinares e procedimentos maleáveis de investigação, requerendo uma integração das diversas áreas dos Estudos Sociais da Infância (MÜLLER; HASSEN, 2009).

Esta investigação com a técnica de observação participante se constitui em uma maneira pelo qual pesquisadores, quando aceitos pelas comunidades investigadas, adotam diversas técnicas de coletas de dados com a finalidade de conhecer mais detalhadamente os modos de vida das pessoas daquele lugar, cria também a possibilidade de o pesquisador interagir cotidianamente com o grupo em diferentes aspectos da vida em sociedade (ANGROSINO, 2009). A observação participante focou nas práticas culturais que se deram nas ações cotidianas das crianças ribeirinhas, grafadas em um registro de campo ou diário etnográfico, conforme denominação de Malinowski (1978).

A partir da observação participante consideramos os seguintes instrumentos, denominados por Alves (2003) como fontes etnográficas, e como instrumentos etnográficos por Mattos (2011), que possibilitaram a coleta de dados: desenhos, bilhetes, cartas, fotografias, filmagens, registro de campo e conversas informais. As fontes etnográficas, mais precisamente aquelas em que há uma expressão genuína dos interlocutores, transcritas tal qual foram expressas por eles, respeitadas assim suas maneiras de escrever, de falar e de ler o mundo. 
Mattos (2011) aponta que para esse tipo de coleta de dados existem algumas formas de análise que podem contribuir para a compreensão do objeto de estudo e que o pesquisador necessita ter clareza sobre qual forma tende a responder melhor aos objetivos propostos na investigação. Dentre as diversas formas existentes optamos pela análise de discurso, que em pesquisa “[...] é analise de um conjunto de ideias, um modo de pensar ou um corpo de conhecimentos expressos em uma comunicação textual ou verbal, que o pesquisador pode identificar quando analisa um texto ou fala" (CHIZZOTTI, 2014, p. 120).

O distrito de Vila do Piriá, município de Curralinho, estado do Pará, Amazônia Marajoara, região Norte do Brasil, é a maior comunidade fora da sede do município, com uma população próxima a 10.000 habitantes, e um contingente de crianças que chega a um percentual de 38,06\% na faixa etária de 0 a 11 anos (IBGE, 2010).

Os critérios para a escolha do lócus de nossa pesquisa foram: a) Ter bastantes crianças; b) Ter acesso facilitado à realização do estudo; c) Ter boa receptividade por parte das crianças para a realização da pesquisa; d) Ser uma comunidade ribeirinha; e) Estar localizado na Amazônia Marajoara.

Localizada às margens do rio Piriá, é considerada área interiorana, de várzea. O grande porte da Vila para os padrões amazônicos nos chamou a atenção, principalmente pelo número considerável de crianças existentes no espaço geográfico. A imagem a seguir mostra a frente da Vila às margens do rio Piriá.

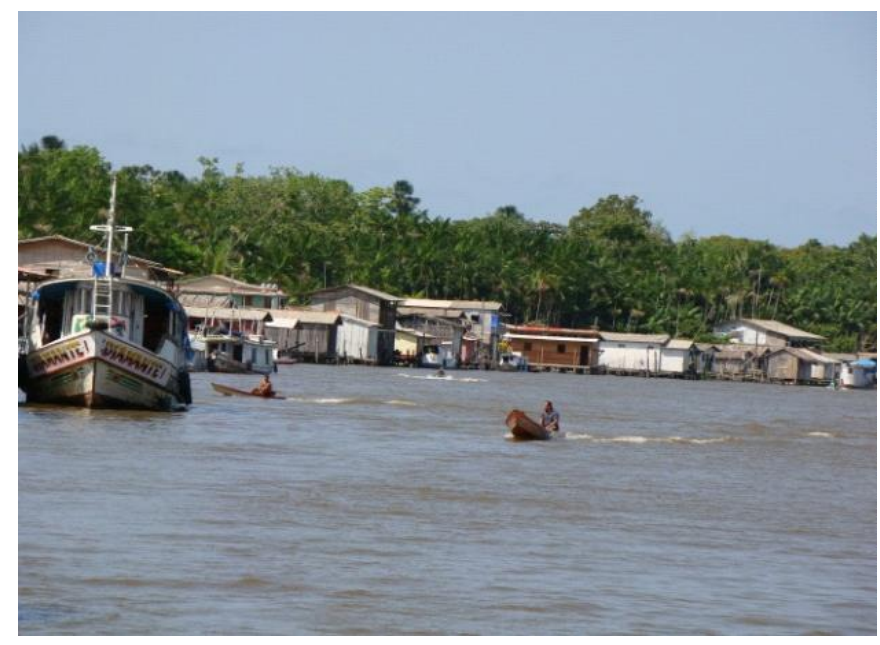

Imagem 1 - Distrito Vila do Piriá - Curralinho/Pará/Brasil Fonte: Arquivo Simei Andrade (2015). 
o que dizem as crianças ribeirinhas da vila do piriá - curralinho/pa - acerca de suas práticas culturais

As primeiras referências bibliográficas encontradas na literatura consultada sobre a Vila do Piriá datam do século XIX; no entanto, pesquisadores apontam que ela pode ter iniciado com a distribuição de terras pelo sistema de sesmarias, ocorrida na região no século XVIII. O Relatório Analítico do Território do Marajó (UFPA/ICSA/MDA/PITCPES/GPTDA, 2012, p. 14) referindo-se aos marajoaras discorre que "[...] essa população foi duramente escravizada pelos portugueses que tomaram para si grandes áreas de terras por meio de concessões de sesmarias".

No início da segunda metade do século $X X$, com a intensificação da exploração e o comércio de madeira na região, a Vila do Piriá se torna um local de beneficiamento de madeiras com a implantação de serrarias. Há indícios de que desde a chegada das primeiras serrarias na localidade, a presença de crianças trabalhadoras com idade entre 9 e 14 anos era uma constante nesses espaços.

A Vila viveu o auge da exploração madeireira entre o início dos anos de 1960 e final dos anos de 1980 (CONCEIÇÃO, 2011), com intensa movimentação de navios de médio e grande portes, nacionais e estrangeiros, que buscavam madeiras em toras e beneficiadas nas serrarias existentes na localidade.

A partir dos anos 2000, todo o processo de extração e beneficiamento de madeira entra em decadência na região, em virtude das novas políticas ambientais e o fechamento de muitas empresas clandestinas na região, que "[...] aliados à histórica insuficiência e ineficiência de políticas públicas, voltadas ao desenvolvimento socioeconômico da região, promoveram um acentuado grau de elevação nas condições de vulnerabilidade da população [...]" (CONCEIÇÃO, 2011), o que tem se perpetuado até os dias atuais.

Nesse contexto, a criança amazônica sempre foi olhada com descaso; sua voz, sem credibilidade na sociedade; de fato, ela tem sido pouco ouvida. Marcílio (2010) esclarece que a criança, até pouco tempo, era considerada inábil, sem condição nenhuma de construir sua identidade; sua vida esteve sempre atrelada ao poder que os pais e ou seus representantes têm sobre os filhos, afirmando que só a partir dos anos de 1950, como consequência da Declaração Universal dos 
Direitos da Criança, ela passa a ser considerada como prioridade no país e tomada como sujeito de direito.

Partindo do pressuposto que a criança é sujeito de direitos, os Estudos Sociais da Infância propõem a defesa de “[...] uma concepção de criança que reconhece o que é específico da infância - seu poder de imaginação, fantasia, criação [...]" (KRAMER, 2011, p. 101), que a perceba como ser concreto, que ocupa um lugar social muito peculiar. Que a considere não como mero objeto de pesquisa, mas sujeito com legitimidade que fala de suas vivências com propriedade, “[...] são ouvidas nas pesquisas como informantes legítimos e deixam de ser estudadas apenas na sua dimensão psicológica, pedagógica ou biológica" (MORAES; ALVES, 2014, p. 304) e assumem novas funções no contexto da investigação científica: o de participantes e copesquisadoras. No caso desta pesquisa, o de participantes.

Os interlocutores foram crianças na faixa etária entre 5 e 11 anos, moradoras da Vila do Piriá. Não nos detivemos, porém, somente a elas, por entendermos que a infância não está desatrelada da cultura ou vivências dos adultos. Portanto, a unidade doméstica (pais, irmãos, avós, tios, vizinhos, padrinhos, amigos, parteiras, professores e outras pessoas da comunidade) também foi ouvida (SOUSA, 2014), o que respaldou ainda mais nossa análise, permitindo perceber, no que diz respeito ao universo ribeirinho, que as crianças e os adultos estão intimamente ligados pelos seus modos de vidas, tão particular e tão expressivo. Embora não tenhamos definido o número de adultos participantes, a própria dinâmica do trabalho nos levou a ouvi-los na contiguidade que se estabeleceu no dia a dia de nossas ações no campo de pesquisa, possibilitando a ampliação de nossas análises acerca das práticas culturais das crianças desse espaço geográfico.

A partir da análise da ficha de perfis das crianças, realizada em 2015/2016, observou-se que os interlocutores estudavam na Vila do Piriá, 92\% na EMEF Maria das Dores Sá e os outros no Centro Municipal de Educação Infantil Canto do Saber (CMEI Canto do Saber); 92\% frequentavam as igrejas evangélicas (Assembleia de Deus; Cristã Evangélica; Evangelho Quadrangular; Assembleia de 
o que dizem as crianças ribeirinhas da vila do piriá - curralinho/pa - acerca de suas práticas culturais

Deus - Ministério Madureira; Deus é Amor; Adventista do Sétimo Dia), as demais frequentavam a Igreja Católica Nossa Senhora de Nazaré. Todos residiam na comunidade; apenas $8 \%$ não residiam com os pais, moravam com parentes, geralmente avós. Também observamos que brincar de pira (nas variações escondecola, doido e n'água), tomar banho no rio (pular n'água, nadar no rio, se esconder dentro d'água), jogar bola (bola no rio) e subir em árvores são as principais brincadeiras das crianças do Piriá.

Apelidos são comuns entre eles (meninos e meninas); 64\% disseram ter algum tipo de apelido, sendo que os mais corriqueiros estão associados aos nomes próprios (diminutivo e reducionismo), nomes de personalidades, nomes de animais e expressões ou balbucios que as crianças utilizam na primeira fase da infância.

Em relação à cor, $40 \%$ se autodeclararam moreno, 32\% branco, $8 \%$ negro e $16 \%$ pardo; apenas um não se autodeclarou. Quanto ao trabalho ou ao exercício de alguma atividade, $48 \%$ afirmaram que não trabalhavam e 36\% disseram exercer algum tipo de tarefa. As atividades na roça, capina, apanhar açaí, colocar matapi, caçar e cortar madeira se constituem um trabalho para homens, por isso são exercidas quase que exclusivamente pelo sexo masculino; já as meninas desenvolvem tarefas domésticas (limpeza da casa, lavar louças, roupas), além de cuidados dos irmãos menores, em alguns casos.

Na Amazônia, a infância vivida pelas crianças é complexa e diz muito do processo histórico de opressão que reflete, ainda hoje, a sua luta diária para sobreviver a tanto descaso, “[...] cuja realidade cultural é marcada pela precariedade social, econômica e política, [...], que na região amazônica, em particular, negligenciou as peculiaridades regionais e as singularidades locais [...]" (SILVA, 2007, p. 48). Observando esse quadro nos ancoramos em Lander (2005) ao considerar que uma das alternativas ao pensamento eurocêntrico-colonial que descuidou das crianças, renegou sua história, é olhar o mundo, agir sobre ele e interpretá-lo, dando-lhe outro significado e principalmente agir de maneira 
consciente, participativa, garantindo que as crianças sejam ouvidas onde quer que estejam.

A realidade social de pobreza e miséria tem marcado a vida dos ribeirinhos da Amazônia Marajoara, explicitada na introdução do Índice de Progresso Social na Amazônia Brasileira/2014 (IPS Amazônia, 2014) ao afirmar "que o cidadão comum desta região enfrenta enormes deficiências em quase todos os componentes do progresso social", o que se comprova nos baixos Índices de Desenvolvimento Humano (IDH) e de Desenvolvimento da Educação Básica (IDEB), na falta de políticas públicas para saúde, educação, infraestrutura e transporte, por exemplo. Ribeiro (2006, p. 280) assevera que “[...] em nenhuma outra região brasileira a população enfrenta tão duras condições de miserabilidade quanto os núcleos caboclos dispersos pela floresta [...]".

É nesse contexto de falta de políticas públicas comprometidas com a população amazônida que buscamos analisar que lugar tem ocupado, neste cenário, a infância vivenciada pelas crianças ribeirinhas, como estas têm sido tratadas em nossa sociedade e como constroem suas histórias, suas práticas culturais, nessa região repleta de diversidades. Compreendemos que:

[...] políticas para a infância precisam ter como horizonte humanização e resgate da experiência, para que crianças e jovens possam ler o mundo, escrever a história, expressar-se, criar, mudar, para que se reconheçam e consolidem relações de identidade e pertencimento [...] (KRAMER, 2011, p. 114).

Apesar de sua extensão territorial, a Amazônia Marajoara também abriga uma extensão de problemas que têm afetado mais diretamente as crianças, como resultado da baixa prioridade nas políticas econômicas e sociais a elas destinadas, demonstrada na sua condição de vida e de morte (ROSEMBERG, 2017).

Os dados são alarmantes: o município de Curralinho, onde realizamos nossa pesquisa de campo, obteve um índice de 0,502 em relação ao Índice de Desenvolvimento Humano Municipal/2010 (IDH-M/2010), ficando na faixa baixa; no ranking nacional ficou na posição $5524^{\mathrm{a}}$, de um total de 5570 municípios do Brasil; no estadual, ocupa a $134^{\mathrm{a}}$ posição, dentre os 144 municípios do estado do Pará. Quanto ao Índice de Desenvolvimento da Educação Básica (IDEB) de 2013, as escolas municipais e estaduais situadas no município que trabalham com o 
o que dizem as crianças ribeirinhas da vila do piriá - curralinho/pa - acerca de suas práticas culturais

Ensino Fundamental ( $4^{\circ} / 5^{\circ}$ ano; $8^{\circ} / 9^{\circ}$ ano) não atingiram a meta estabelecida pelo Ministério da Educação.

Esse quadro demonstra que, embora a localidade seja exuberante, cercada por rios e floresta, a realidade de infortúnio de sua população não reflete a beleza que está a sua volta

[...] as condições de pobreza do povo vêm se agravando nas últimas décadas. Certamente mais de $90 \%$ da população é pobre, muito pobre, muitos em situação de miséria absoluta. Além disso, no contexto da política econômica dos Governos Federal e Estadual não se consegue detectar medidas que permitam visualizar no horizonte o combate direto à pobreza desse povo, o que permite concluir que essas populações estão condenadas à marginalização social por tempo indeterminado (HERMOSO; RIVATO apud SOUZA, 2015, p. 101).

É nessa região de contrastes que buscamos mostrar “[...] que a dívida brasileira para com crianças não decorre apenas da desigual distribuição de rendimentos pelos segmentos sociais, mas também da desigual distribuição dos benefícios das políticas sociais [...]" (ROSEMBERG; ARTES, 2012, p. 18).

\section{práticas culturais no cotidiano das crianças ribeirinhas}

Trazemos à baila o termo práticas culturais infantis no plural, pois são muitas práticas que advêm de diversas culturas infantis que por sua vez se constroem nos universos de tantas infâncias (CANAVIEIRA; CALDERON, 2011).

As práticas culturais estão atreladas ao cotidiano da população, evidenciando "[...] um verdadeiro universo povoado de seres, signos, fatos, atitudes, que podem indicar múltiplas possibilidades de análise e interpretação [...]" (LOUREIRO, 2000, p. 69). É neste universo que as práticas culturais das crianças ribeirinhas da Vila do Piriá são marcadas por suas vivências no brincar, na escola, na igreja, na via pública, na sua forma de expressão corporal, de gesticular, na oralidade, nas manifestações culturais, nas relações que estabelecem consigo, com seus pares, com os adultos e com a natureza, desenvolvendo ações sobre a cultura material e imaterial.

Consideramos que todos os aspectos que compõem a infância e as crianças ribeirinhas são importantes para a compreensão da identidade desses sujeitos (SOUSA, 2014) e suas práticas culturais, visto que “[...] as crianças, por terem uma 
enorme plasticidade da renovação das formas e dos conteúdos, poderão propor e sugerir outros modos de ver o mundo que não aqueles cristalizados nas culturas dominantes" (SARMENTO, 2017, p. 6), como podemos contemplar nas imagens a seguir:

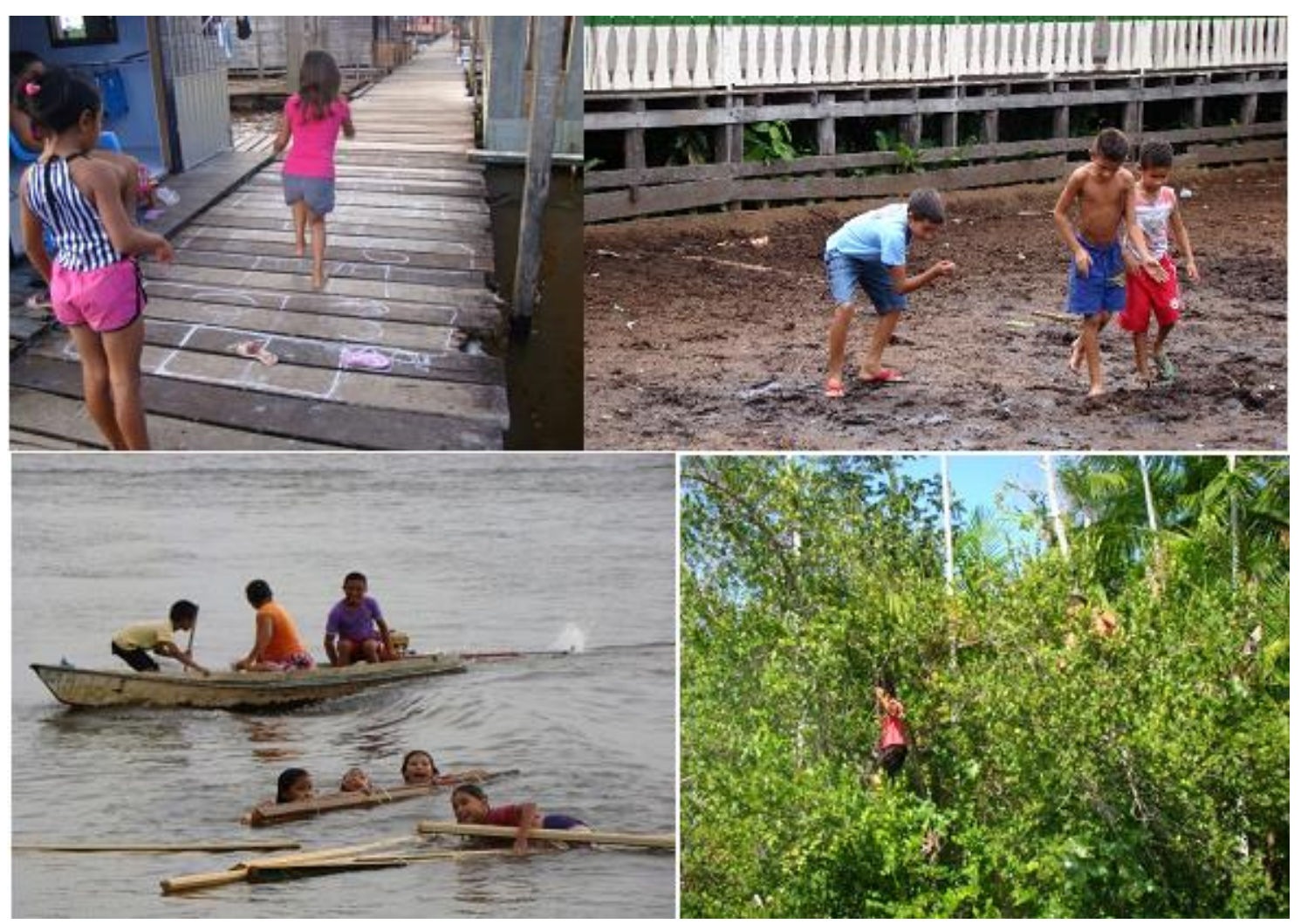

Imagem 2 - Crianças no exercício de suas práticas culturais na Vila do Piriá. Fonte: Simei Andrade (2015/2016/2017).

Refletir as práticas culturais das crianças ribeirinhas a partir do que dizem sobre si e o mundo no qual estão imersas nos leva a perceber a infância vivenciada na comunidade. Este exercício nos auxiliará a entender que lugar as crianças têm nesta cultura, as características relevantes da infância ribeirinha, as práticas culturais realizadas pelas crianças a partir de suas vivências com a natureza, com o corpo, a afetividade e a cultura local.

Como forma de garantir que as práticas culturais permaneçam vivas na comunidade, a oralidade se constitui num mecanismo específico de perpetuação dos modos de vida dos ribeirinhos. As crianças possuem um jeito muito próprio de externar suas ideias, encontrando na oralidade sua melhor forma de expressão. 
o que dizem as crianças ribeirinhas da vila do piriá - curralinho/pa - acerca de suas práticas culturais

Falar de suas vivências seduz o ouvinte, contando histórias, causos, com muita emoção, o que se traduz numa fala elaborada com um linguajar próprio do lugar e gesticulações que dão ênfase e ajudam o outro a entender o que estão a dizer. É pela oralidade que elas dizem de si, da sua cultura, do seu universo. Portanto, a fala é a manifestação aberta, pura e sensível do sujeito-criança (BENJAMIN, 2011). Também Certeau observa que "A linguagem produzida por uma categoria social [Infância] dispõe do poder de estender suas conquistas às vastas regiões do seu meio ambiente, [...]" (CERTEAU, 2014, p. 89; grifo nosso), constituindo-se a oralidade em um instrumento de luta capaz de dar novo significado à vida dos sujeitos-atores da Amazônia.

A oralidade dá o tom da vida cotidiana para o ribeirinho, fluindo naturalmente na voz gritante, rouca, aguda e amena dos pequenos, não como um amontoado de palavras, mas como algo que se dissipa nas suas vozes e nos sons que acompanham sua história (BENJAMIN, 2011).

É por meio da oralidade que as práticas culturais, na Amazônia, vêm sendo passadas para as gerações seguintes. Além de ver e ouvir "como faz" ou "como é", as crianças ressignificam tais práticas e dão a elas um novo sentido.

É preciso dizer que não tivemos a ousadia de considerar, nessa pesquisa, todas as práticas culturais das crianças ribeirinhas da Vila do Piriá até seu esgotamento sob todas as dimensões possíveis e imagináveis que porventura ocorram naquele espaço. Analisaremos neste ensaio, de forma pontual, somente quatro práticas culturais, aquelas que emergiram com mais frequência em nossa pesquisa de campo: piras; banho de rio; narrativas orais sobre seres encantados; e pesca do camarão: fabricação e utilização do matapi.

\section{brincadeira de pira}

$\mathrm{Na}$ infância existem aprendizados que fazem parte do universo das crianças, que compõem suas práticas culturais, sendo um dos mais pertinentes o brincar. Na narrativa a seguir podemos observar a infância sendo vivenciada pelas crianças que brincam de pira num espaço em plena floresta amazônica, expressando, cada uma a sua maneira por meio das ações que compõem as 
práticas culturais infantis, suas experiências, sendo que por meio destas elas apreendem o mundo (SOUSA, 2014), e que as torna um ser singular.

\section{O brincar como prática cultural}

Registro de campo (03/09/2015)

Caminhávamos pela única estrada de chão da Vila, a Transpiriá, e perto da quadra poliesportiva encontramos um grupo de 8 (oito) crianças brincando de pira, ou melhor, pira se esconde-cola (que nos pareceu ser a junção de duas variações de pira, a se esconde ${ }^{5}$ e cola $\left.{ }^{6}\right)$, estando algumas já dentro da mata de igapó, das quais só se ouvia a voz e a respiração acelerada. O local era propício à brincadeira, mata fechada, o que facilitava a embrenhação na floresta. Ficamos um pouco afastadas do grupo, apenas observando a movimentação. No primeiro momento, 5 (cinco) crianças se juntaram, e percebemos então que estavam organizando as regras do jogo. Uma delas (Aline) se afasta, ficando de costas para os demais, e agarra-se, de olhos fechados, numa árvore, iniciando em voz alta uma contagem que foi decidida pelo grupo que seria de 1 a 100, no entanto, à medida que os números eram falados em voz alta por Aline, notamos uma aceleração na voz e os números eram ditos rapidamente; até o número 30 seguia normal, depois eram pulados, de 30 passava para $38,42,54 \ldots$ até chegar em 100 . O restante do grupo correu para dentro da mata. Aproximamo-nos do local e vimos crianças subindo em árvores, em troncos de madeira, escondidas atrás das folhagens, correndo com espantosa habilidade numa mata de difícil acesso. Ao terminar a contagem Aline sai correndo para dentro da mata, buscando pegar ou colar alguém. De repente, sem poder identificar quem falava, pois só escutávamos sussurros, risadas, gritos e assovios, como se fossem gorjeio de um bando de pássaros, ouvimos:

- Corre, corre, te esconde! Lá vem ela - a mãe, a que pega!

- Fala baixo. Ei, Alê, cadê todo mundo?

- Tá escondido, huhu, cadê tu, Roberta, Arlan? (voz muito baixa)

- Cadê tu, Alessandra?

Aline então diz, pulando em cima do colega:

- Há, há, há, te peguei, Arlan! Tu tá colado! Não adianta, vou pegar todo mundo.

Arlan, colado, não pode sair do lugar, no entanto, seus pares, cercando a área próxima, porém todos tentando ficar invisíveis para a "mãe" não vêlos, tentam tocá-lo, mas Aline não permite, fazendo menção que irá correr atrás deles para colá-los ou então correr para o pique e dizer em voz alta que achou alguém em determinado local. Enquanto Aline tenta

\footnotetext{
${ }^{5}$ Também conhecida como pique esconde, pega-pega ou pegador, é uma das muitas variações do jogo de pira, categorizado como um jogo de perseguir, procurar e pegar. A pira se esconde se caracteriza por ser um jogo em que uma criança é escolhida para ser a "mãe" ou o "pegador", ela esconde o rosto e inicia uma contagem que varia de 30 a 100, enquanto as demais se escondem. Após a contagem, a "mãe" tem que encontrar todos para sair vencedor no jogo. Sempre que encontrar alguém tem que sair correndo para bater no pique (ponto ou local escolhido pelo grupo onde quem tocar primeiro está salvo), dizendo "peguei" ou "achei" ou "toquei" (diz o nome da pessoa localizada e o local onde ela está), ex: achei a Alê debaixo da ponte. Caso a criança que foi localizada pela "mãe" chegar ao ponto primeiro, ela ganha. A "mãe" continua a procurar os demais que ainda estão escondidos (FRIEDMANN, 2004; ANDRADE, 2013).

${ }^{6}$ Chamado também de pique cola é outra variação do jogo de pira. A brincadeira inicia quando uma criança é escolhida para ser a "mãe" ou o "pegador", ela tem de correr atrás dos demais, caso consiga pegar ou tocar um dos participantes, a criança tocada fica parada no local, como se estivesse colada. Se outra criança tocar nela, então fica descolada e volta ao jogo. Quando a criança é colada três vezes, ou quantas forem determinadas pelo grupo, passa a ser a "mãe" (FRIEDMANN, 2004; ANDRADE, 2013).
} 
o que dizem as crianças ribeirinhas da vila do piriá - curralinho/pa - acerca de suas práticas culturais

pegar os demais, Ruan toca em Arlan, que volta a ficar descolado e pode se esconder e correr novamente. Todos correm para o interior da mata, Aline se vê sozinha, e se referindo talvez a Arlan ou Ruan, diz:

- Oooooi, cadê tu, porque tá todo mundo escondido? Cês num querem brincá mais? Tô indoooo.

A ideia de Aline nos pareceu com aquele ato meio despretensioso de ir embora, e à medida que as crianças fossem saindo da mata, ela então correria para colar quem aparecesse. Naquele momento a pergunta de Aline reverbera na mata e na nossa mente, então reformulamos a pergunta; a partir do nosso referencial epistemológico de pesquisadora inserida numa dada realidade - a Amazônia Marajoara - nos perguntamos: Como vivem as crianças deste espaço? O que falam as crianças da Vila do Piriá acerca de suas culturas e práticas culturais? Naquele instante, percebemos que elas tinham muito a dizer sobre o mundo no qual estavam inseridas, sobretudo o cotidiano dinâmico e com muitas ações realizadas por meninos e meninas em lugares diversos: rios, matas, campos de natureza, sítios...

No geral o jogo de pira é muito contagiante, a participação do grupo é intensa. É uma modalidade de jogo que possui algumas variantes (piras escondecola, alta, parede, maromba, pega...) e ocorre com bastante frequência na Vila. Possibilita o uso do corpo, pois requer muita destreza no movimento da criança, que faz uso do ambiente, explorando os lugares mais inusitados de acordo com as regras estabelecidas em cada variante.

A pira é considerada um jogo, pois tem regras de funcionamento "[...] em que um indivíduo corre atrás dos demais tentando pegá-los. O toque do "pegador", também chamado de "mãe", no outro é o que marca o movimento dos brincantes no jogo" (ANDRADE, 2013, p. 86). Observamos no brincar das crianças que o jogo de pira envolve alguns passos: a escolha da "mãe", o desenvolvimento do jogo por meio de tentativas de pegar e do rodízio de pegadores, e a conclusão, quando o grupo é colado ou todos conseguem ser mais ágeis que a "mãe" e vencem o jogo.

A brincadeira de pira faz parte da dinâmica da vida das crianças ribeirinhas da Amazônia Marajoara, sendo uma das brincadeiras mais citadas no levantamento do perfil das crianças. A pira traduz um momento de descontração e interação das crianças (ANDRADE, 2013), podendo acontecer de dia ou de noite, enquanto as crianças ainda estão se deslocando de um lado a outro da comunidade. 


\section{banho de rio}

A relação estabelecida com a natureza mostra que o sujeito-criança ribeirinho acostumado desde cedo com o rio, encontra-se seguro neste ambiente, seja nadando, pescando, brincando, ou seja, sente-se seguro desenvolvendo suas práticas culturais.

Desde a mais tenra idade as crianças, numa prática diária, são levadas, primeiramente, pelos pais ou responsáveis ao rio, e seguras nos troncos são mergulhadas diretamente nas águas barrentas dos rios da Amazônia. Essa prática de banhar-se no rio se torna intensa, e à medida que as crianças crescem começam a ter certa autonomia de vivência nas águas, indo banhar-se sozinhas ou com seus pares, sem a interferência dos adultos, chegando ao número de 4 a 6 banhos por dia. Coelho, Santos e Silva (2015) nos esclarecem que

[...] partes significativas das crianças ribeirinhas, aproximadamente dos três aos cinco anos de idade, dominam habilidades necessárias do ato de nadar e adquirem habilidades para andar em cima de troncos flutuantes, como o de buriti, sustentando-se em troncos de árvores, no próprio casco, sobre as costas de outras pessoas, ficando de pé nas partes mais rasas do rio até conseguir a habilidade necessária para nadar sozinhas (COELHO; SANTOS; SILVA, 2015, p. 65)

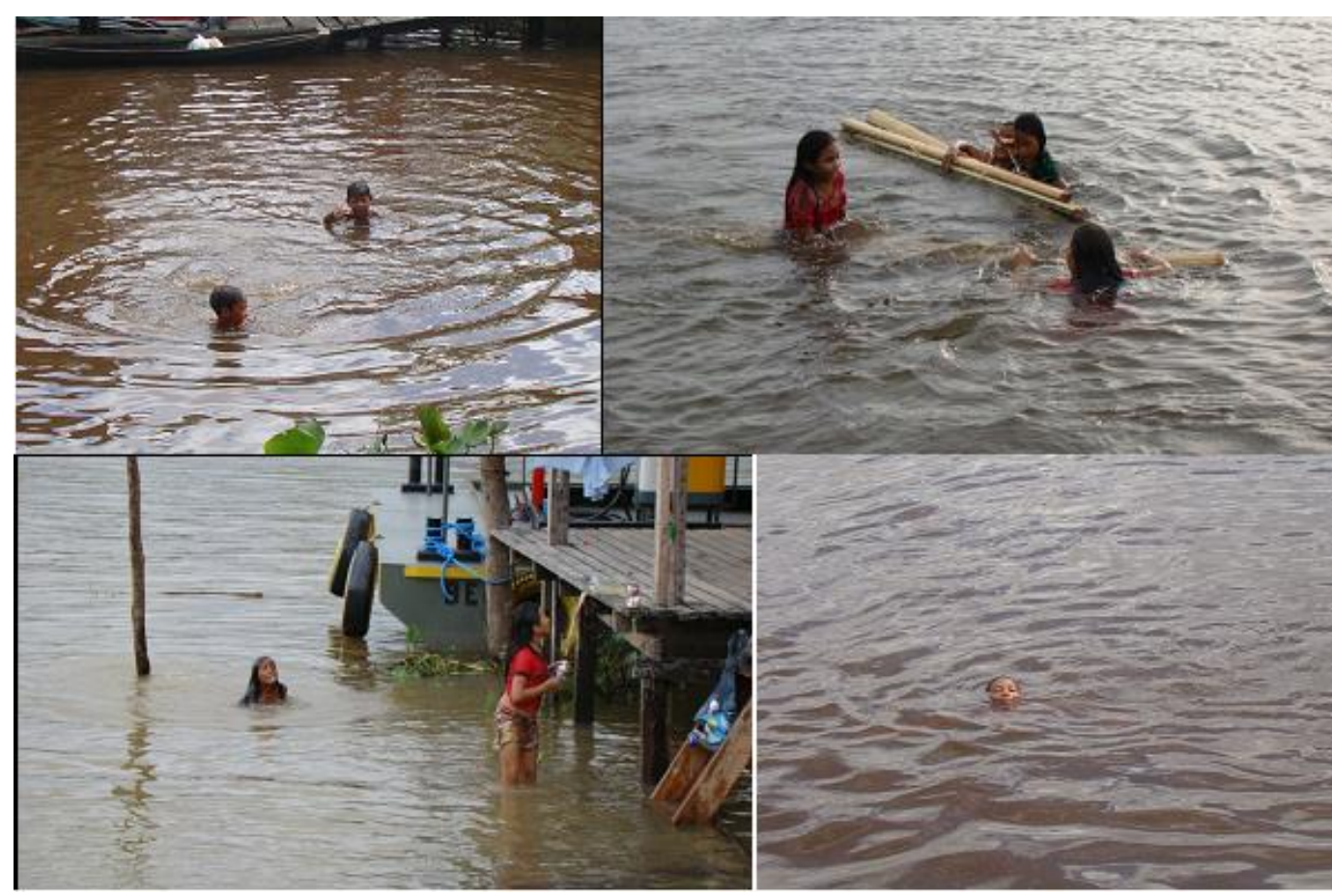

Imagem 3 - A prática cotidiana do banho de rio.

Fonte: Simei Andrade (2015/2016). 
o que dizem as crianças ribeirinhas da vila do piriá - curralinho/pa - acerca de suas práticas culturais

A prática de banhar-se no rio propicia a integração da criança com o ambiente do rio; ela percebe a limitação do corpo diante das adversidades do rio, desenvolve habilidades e potencialidades e conhece e ressignifica as técnicas de pescar, de navegação, de conhecimento das marés e etc.

Banhar-se no rio, embora seja uma prática cotidiana, vai sendo apropriada pelas crianças gradativamente, com o contato diário, várias vezes ao dia. Esse contato com o rio permite a expansão corporal, possibilitando à criança o exercício da ludicidade, momento em que elas fazem acrobacias no rio, porfiam para ver quem chega primeiro a um determinado ponto, brincam de pira pega e cola, flutuam em tronco de árvores, enfim, brincam livremente nas águas barrentas dos rios da Amazônia. No fragmento do nosso registro de campo podemos observar a desenvoltura das crianças brincando no rio: Kaline, 4 anos; e Isis, 5 anos.

Kaline: Gosto de tomá banho na água.

Isis: Ela toma banho comigo de pega-pega.

Kaline: Né, Isis, a gente nada muito na água, brinca de pira pega, a gente pula lá de cima da rampa, né, Isis? De cima do trapiche.

As crianças têm intimidade com o rio, o que possibilita o exercício da ação livre, espontânea, no qual elas se banham e brincam ao mesmo tempo. Tomar banho de rio, além de ser um ato que faz parte da higiene das pessoas, é uma experiência transmitida espontaneamente, acompanhando a dinâmica da vida social, constituindo-se numa prática cultural.

\section{narrativas orais - seres encantados da água}

Na Amazônia o imaginário das crianças é encharcado de histórias, causos, lendas e seres encantados que "[...] constituem pistas, mensagens que dizem respeito ao universo interior [...]" (FRIEDMANN, 2013, p. 90) delas.

O imaginário é uma linguagem que se multiplica, conforme nos referenda Certeau (2010), e passa de uma geração a outra, por meio da oralidade; essa tem sido a forma com que as crianças ribeirinhas têm guardado na memória um vasto repertório de histórias que constitui “[...] os saberes das culturas seculares dos povos das florestas [...]" (POJO; VILHENA, 2013, p. 141). 
Na Vila do Piriá o imaginário se dá por manifestações que surgem sobretudo das águas. Vindos do rio, identificamos o Jacaré Grande do Piriá e a Cobra Grande do Piriá. As narrativas dos pequenos amazônidas traduzem verdades sobre o imaginário, o qual desempenha um papel importantíssimo na produção cultural amazônica, como “[...] processos sociais que estruturam e são estruturados pelas crianças enquanto actores nas acções sociais que desenvolvem no contexto coletivo [...]" (FERREIRA, 2004, p. 65). Falando de encantarias, de mítico, suas falas traduzem a cultura do lugar; “[...] essas são as histórias que elas conhecem e fazem parte do seu cotidiano" (LOPES, 2012, p. 131). A Amazônia, por ser tão imensa, possui uma variedade de seres encantados, alguns deles adaptados à realidade local, e que foram objeto das narrativas das crianças da Vila do Piriá, portanto, merecem destaque:

\section{jacaré grande do piriá}

É muito comum se ouvir que as cidades da Amazônia, por ficarem geralmente às margens de rios, são sustentadas por animais de porte gigantesco, seres imensos que sobrevivem há muitos anos no local, como cobras grandes, por exemplo. Sobre esse aspecto Loureiro (2007) considera que

As encantarias amazônicas são uma zona transcendente que existe no
fundo dos rios, espécie de olimpo submerso, habitadas pelas divindades
encantadas no íntimo de todas as coisas, e que compõem a teogonia
amazônica. É dessa dimensão de uma outra realidade que emergem para
superfície dos rios e do devaneio os botos, as iaras, a boiúna, a mãe
dágua, as melodias sedutoras cantadas por invisíveis sereias, as
entidades plásticas do fundo das águas e do tempo [...] (LOUREIRO,
2007, p. 46).

São divindades encantadas que compõem o imaginário dos amazônidas, em especial das crianças. Na Vila do Piriá, o animal que mantém a Vila em pé é um enorme jacaré, segundo relato dos nossos sujeitos-crianças; "muita gente já viu" (Pedro Henrique, 8 anos). É tão grande que já virou embarcações de porte considerável, "rabudo7 então, não tem conta. Quando a água tá grande, não gosto nem de andar muito por aí" (Kailana, 9 anos), “[...] o rio torna-se, portanto, como uma coisa

\footnotetext{
${ }^{7}$ Embarcação de pequeno porte, usada pelos ribeirinhos, que dispõe de um motor instalado em uma de suas extremidades (popa).
} 
o que dizem as crianças ribeirinhas da vila do piriá - curralinho/pa - acerca de suas práticas culturais

viva da qual tudo pode vir, como de tudo o que é vivo, de tudo o que tem vida [...]" (LOUREIRO, 2000, p. 194).

As águas do rio Piriá são barrentas, escuras, o que instiga ainda mais o imaginário das crianças. Uma criatura de tamanho gigantesco pode a qualquer momento emergir do rio. O interessante é que o fato de o Jacaré Grande viver no rio, não as impede de brincar e tomar banho a qualquer hora neste lugar.

O bicho parece ser grande mesmo, "tem olho bugalhado, boca gradona que come uma gente de uma vez. Corre de uma ponta noutra no rio num mergulho só, de tão porrudo que é" (Keila, 8 anos). "Quanto mais grande tiver a maré, mais o jacaré se mexe no rio" (Pedro Henrique, 8 anos). "Outro dia o jacaré ia agarrando o mudo ali no outro lado. Ele tava mijando do outro lado da escada, da primeira escada, o jacaré tava só olhando pra ele. Na hora que ele mergulhou, ele viu borbulho, ele pensava que não um jacaré tava só mirando ele" (Keila, 8 anos). Nas narrativas percebe-se que há uma ênfase nas falas para garantir a veracidade dos fatos "[...] nosso devaneio é incansável, interfere na realidade, poetizando a relação pregnante com essa realidade, o que faz com que, tantas vezes, o imaginário seja mais real do que o real [...]" (LOREIRO, 2007, p. 17).

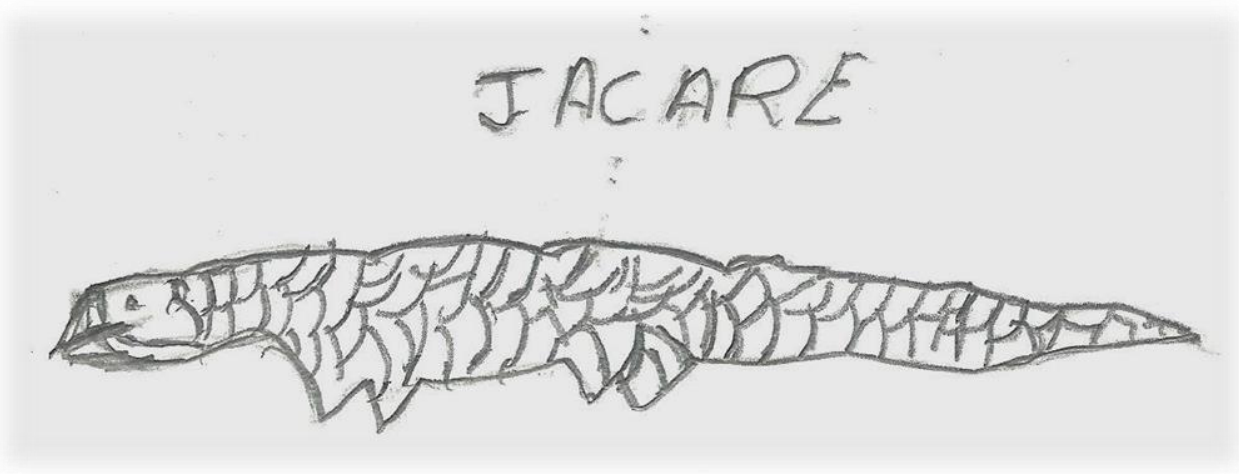

Figura 1 - Representação do Jacaré Grande do Piriá.

Arlan, 11 anos

Fonte: Pesquisa de campo (2016).

O Jacaré Grande do Piriá está presente no imaginário de grande parte das crianças da Vila. Nas conversas informais observamos que o bicho se mostra como aquele que habita as profundezas do rio, faz parte daquele universo e não sobreviveria em nenhum outro lugar, somente no rio Piriá. Ao mesmo tempo em 
que se mostra como uma criatura a ser temida, ocorre uma espécie de apropriação do bicho pelas crianças, que quando se referem a ele fazem questão de afirmar que ele é "do Piriá"; portanto, o jacaré se torna integrante da cultura local das crianças.

\section{cobra grande do piriá}

O município de Curralinho constitui cenários deslumbrantes para a morada de um dos animais mais temidos da região - a Cobra Grande - também chamada de boiúna; “[...] o rio é o lugar dos encantados, dos sujeitos misteriosos, detentores de poderes que mundiam as pessoas, mas que também seduzem, provocam prazer [...]" (ALVES, 2007, p. 147).

Loureiro (2000) destaca que há inúmeras narrativas desse mito que percorre deslizando os rios da Amazônia: seja como uma criatura do mal, seja como devorador de tudo que encontra, seja alagando as embarcações que teimam em passar na sua frente, seja tragando a vida dos velhos, seja na forma de fantasma, ou ainda cegando, ensurdecendo ou mesmo enlouquecendo as pessoas que cruzam seu caminho.

Para as crianças ribeirinhas a história desse animal vai além de uma lenda, mas se constitui num cruzamento entre o visível e o invisível (LOUREIRO, 2000). A Cobra Grande do Piriá está sempre presente na narrativa das crianças como um mito sobre o qual escutam desde que nasceram, pela boca dos avós, pais, tios, padrinhos e pessoas mais velhas da comunidade. "Lá em casa a tia sempre conta pra gente que tem uma cobra grandona aí no rio, tem vez que fica até brilhante"; "É verdade que tem mina de bicho aqui, tem uma cobra muito enorme aqui" (Keila, 8 anos); "Um amigo meu me disse que ele tava sentado na cabeça do trapiche, mermo ali, era uma hora mais ou menos, buiou uma cobra assim: ela olhou pro lado, olhou pro outro e só fez mergulhá (Bambam, 11 anos). Deste modo, o rio Piriá reflete o imaginário das crianças da Vila, que se manifesta na maneira como veem e descrevem o mito da cobra grande. $\mathrm{O}$ desenho a seguir mostra a ideia que as crianças fazem da Cobra Grande do Piriá. 
o que dizem as crianças ribeirinhas da vila do piriá - curralinho/pa - acerca de suas práticas culturais

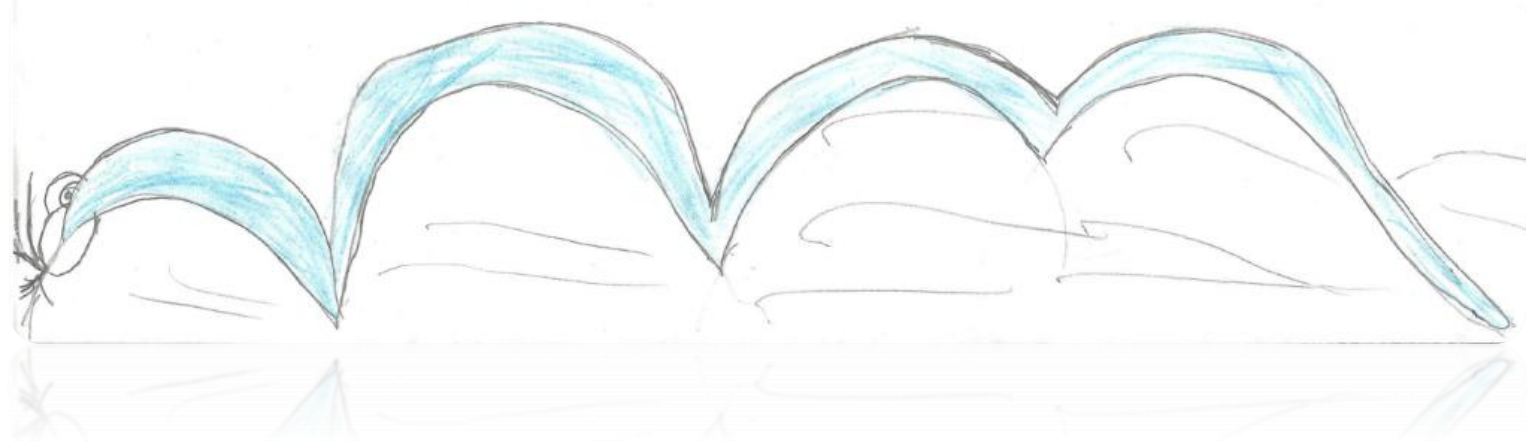

Figura 2 - Representação da Cobra grande do Piriá.

Roberta, 8 anos.

Fonte: Pesquisa de campo (2016).

No dia a dia das crianças o imaginário se reflete naturalmente. Nas conversas às margens do rio, na ponte, no ir e vir diário, histórias simples, porém profundas, são partilhadas. Portanto, “o cotidiano é aquilo que nos é dado cada dia (ou que nos cabe em partilha)" (CERTEAU, 2013, p. 31). Contar episódios como o narrado acima é dizer de uma dada realidade, do que é importante ser dito pelos seus atores.

\section{pesca do camarão: fabricação e utilização do matapi}

A fabricação do matapi pelas crianças envolve conhecimentos trazidos pelos adultos (pais, avós, tios...) e ressignificados por elas. Uma das crianças interlocutoras do estudo, Paulo dos Vales, de 8 anos, relata o processo de fabricação.

\footnotetext{
Matapi serve pra pegá camarão. Pra fazê o matapi é assim, a gente aprendeu com o pessoal aí. Corta o arumã, tira toda a folha e deixa secá no sol aquela casca dele, depois quando tiver seco corta os pedaços, as talas, pega o cipó e amarra pedaço por pedaço, vai formando um negócio parece uma casinha, depois faz as portinhas para colocá a isca. Pra pegá o camarão, nós coloca o matapi dentro d'água e amarra com o fio num toco pra maré não levá. Pra vim o camarão nós coloca cuí de farinha dentro ou se tivé ração coloca dentro de um saco, fura e deixa o camarão senti o cheiro, aí ele vem comê, quando ele entrá no matapi, ele não sabe mais saí, fica preso, de manhã é só puxá o matapi e tirá o camarão que ficou preso (PAULO DOS VALES, 8 ANOS).
} 


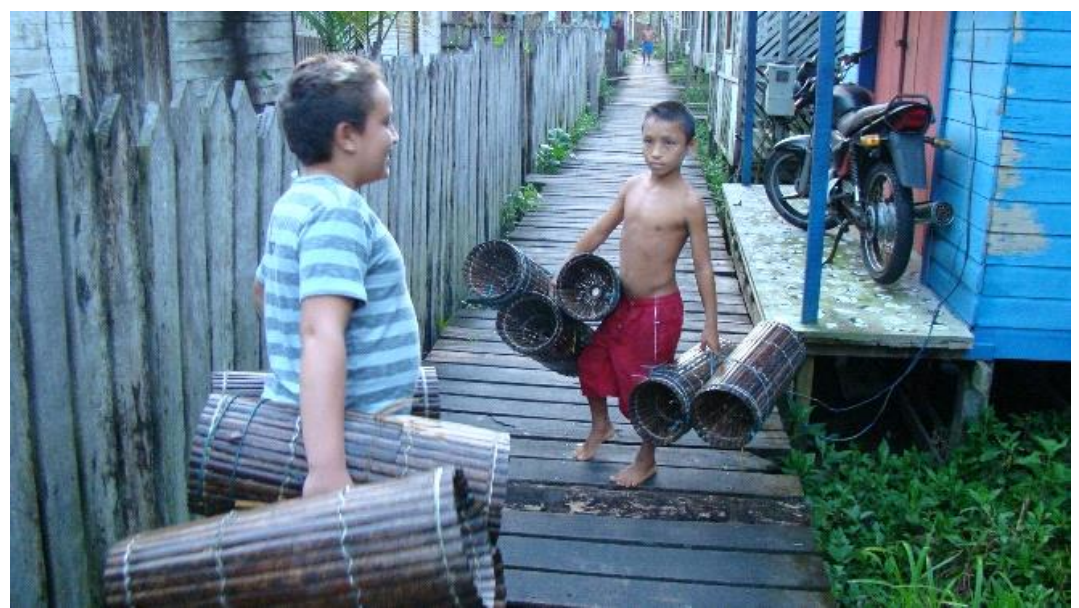

Imagem 4 - Crianças indo colocar matapi no rio Piriá. Fonte: Arquivo Simei Andrade (2016).

A pesca do camarão de água doce por meio da utilização do manuseio do matapi pelas crianças se constitui uma prática cultural secular herdada dos índios que viviam na região do Marajó, sendo uma atividade frequente no cotidiano delas. Conforme narrado pelas crianças, é feito de material extraído da natureza, fibra vegetal (tala de arumã) e tem formato cilíndrico (imagem 4), medindo cerca de $50 \mathrm{~cm}$ de comprimento e $25 \mathrm{~cm}$ de diâmetro, com um funil nas suas extremidades que facilita a entrada do camarão ao mesmo tempo em que dificulta sua saída; a isca é feita de farinha de mandioca, base alimentar dos ribeirinhos, portanto, fácil de encontrar.

Observamos que quando se aproximava o horário de puxar o matapi da água as crianças iam em grupos, e se ajudando conseguiam retirar o camarão pescado, o qual servia para o consumo das próprias crianças e suas famílias.

O matapi é uma espécie de armadilha, colocado ao longo do rio Piriá, geralmente às suas margens. A confecção do artefato é uma prática que vem sendo passada de geração para geração, sendo colocado na baixa-mar e retirado na preamar pelas crianças. O processo de confecção do matapi é apreendido em todas as suas fases pelas crianças, desde a extração das talas do arumã, amarração e a colocação do funil, passando pela noção matemática para saber medir a distância, tamanho e etc., do instrumento, o que contribuía para que o camarão que entrasse na armadilha tivesse o tamanho adequado para o consumo, não pescando o camarão miudinho. 
o que dizem as crianças ribeirinhas da vila do piriá - curralinho/pa - acerca de suas práticas culturais

Essa prática cultural de fabricação e utilização do matapi na pesca do camarão requer saberes que estão atrelados às vivências das crianças na Vila do Piriá e se perpetuam à medida que as novas gerações continuam o processo de transmissão dessa cultura.

\section{considerações finais}

O estudo objetivou analisar o que falam as crianças da Vila do Piriá acerca de suas práticas culturais vivenciadas no cotidiano da Amazônia Marajoara. As crianças dominam saberes atrelados às vivências que norteiam suas práticas sociais e culturais, têm a capacidade de dizer do seu lugar de uma maneira simples, concreta e sensível.

A pesquisa com crianças in loco nos mostrou que elas são ativas e receptivas, que comunicam a vida intensamente, colocando suas capacidades em funcionamento, objetivando a participação na vida cotidiana com todos os aspectos de sua personalidade (HELLER, 2014). Compreendemos, assim, que as crianças da Vila do Piriá são sujeitos do presente, dispostos e motivados a dar um novo sentido ao seu dia a dia.

A despeito de dominarem os saberes permeados pelas práticas socioculturais, concluímos que o cotidiano das crianças ribeirinhas é marcado pela escassez de políticas públicas que lhes assegurem condições de viverem com dignidade, respeitando sua condição de pequenos cidadãos. Políticas que visem a um movimento horizontal humanizado, que resgatem a experiência, a leitura de mundo, suas histórias de vida, de modo a reconhecer e consolidar as relações de identidade e pertencimento da criança da Amazônia Marajoara.

Espera-se que este estudo possa produzir reflexões críticas sobre o lugar que as crianças amazônicas têm ocupado na sociedade e nas discussões acadêmicas; que saberes produzem e estão escondidos sob a ótica do descaso, da fragilidade, da falta de credibilidade do que afirmam, especialmente das práticas culturais tão presentes no seu cotidiano. 


\section{referências}

ALVES, Laura Maria Silva Araújo. A constituição do discurso narrativo polifônico da criança: traços da mitopoética amazônica. In: ALVES, Laura Maria Silva Araújo (Org.). Educação Infantil e estudos da infância na Amazônia. Belém: EDUFPA, 2007. p. 133-167.

ALVES, Vânia de Fátima Noronha. O corpo lúdico Maxacali: segredos de um "programa de índio". Belo Horizonte: FUMEC-FACE, C/ Arte, 2003.

ANDRADE, Simei Santos. O lúdico na vida e na escola: desafios metodológicos. Curitiba: Appris, 2013.

ANDRÉ, Marli Eliza Dalmazo Afonso de. Etnografia da Prática Escolar. 16. ed. Capinas: Papiros, 1995.

ARENHART, Deise. Culturas infantis e desigualdades sociais. Petrópolis: Vozes, 2016.

BENJAMIN, Walter. Origem do drama trágico alemão. Edição e trad. de João Barrento, Belo Horizonte: Autêntica, 2011.

CANAVIEIRA, Fabiana Oliveira; CALDEIRON, Ana Cláudia. Relações entre as crianças pequenas e a produção das culturas infantis: vistas, ouvidas e citadas. In: SILVA, Adriana; CALDEIRON, Ana Cláudia, SANTOS, Cândida Maria; ALVES, Daltro. et al. Culturas infantis em creches e pré-escolas: estágio e pesquisa. Campinas: Autores Associados, 2011.

CERTEAU, Michel. A cultura no plural. Tradução Enid Abreu Dobránszky. 6. ed. Campinas: Papirus, 2010.

CERTEAU, Michel de. Anais do cotidiano. In: CERTEAU, Michel; GIARD, Luce; MAYOL, Pierre. A invenção do cotidiano: 2 morar, cozinhar. Tradução de Ephraim F. Alves e Lúcia Endlich Orth. 12. ed., v. 1, Petrópolis: Vozes, 2013.

CERTEAU, Michel de. A invenção do cotidiano: artes de fazer. Tradução de Ephraim Ferreira Alves, 21. ed., v. 1, Petrópolis: Vozes, 2014.

CHIZZOTTI, Antonio. Pesquisa qualitativa em ciências humanas e sociais. 6. ed. Petrópolis: Vozes, 2014.

COELHO, Wilma de Nazaré Baía; SANTOS, Raquel Amorim dos; SILVA, Rosângela Maria de Nazaré Barbosa e. Educação e diversidade na Amazônia. São Paulo: Editora Livraria da Física, 2015.

CONCEIÇÃO, Anderson dos Reis. Acirramento da "Questão Social" no município de Breves: o alcance do Programa Bolsa Família. Disponível em: <http://www.joinpp.ufma.br/jornadas/joinpp2011/CdVjornada/EIXO_DESIGUAL DADES_SOCIAIS_E_POBREZA.htm>. Jornada Internacional de Políticas Públicas, Eixo: desigualdades Sociais e Pobreza. São Luis/MA, de 23 a 26 de agosto de 2011.

CORSARO, William A. Sociologia da infância. Tradução de Lia Gabriele Regius Reis. Portp alegre: Artmed, 2011.

COUTINHO, Angela Scalabrin. Os novos estudos sociais da infância e a pesquisa com crianças bem pequenas. Revista Educativa, Goiânia, v. 19, n. 1, p. 762-773, set./dez. $2016 . \quad$ Disponível em: <http://seer.ucg.br/index.php/educativa/article/viewFile/5426/2980>. Acesso em: 22 abr. 2017.

FERREIRA, Manuela. «A gente gosta é de brincar com os outros meninos!» relações sociais entre crianças num Jardim de Infância. Porto: Edições Afrontamento, 2004.

FRIEDMANN, Adriana. A arte de brincar: brincadeiras e jogos tradicionais. 3. ed. Petrópolis: Vozes, 2004.

FRIEDMANN, Adriana. Linguagens e culturas infantis. São Paulo: Cortez, 2013. 
o que dizem as crianças ribeirinhas da vila do piriá - curralinho/pa - acerca de suas práticas culturais

GONSALVES, Elisa Pereira. Conversas sobre iniciação á pesquisa científica. Campina: Alínea, 2001.

HELLER, Agnes. O cotidiano e a história. Tradução de Carlos Nelson Coutinho e Leandro Konder, 10. ed. São Paulo: Paz e Terra, 2014.

IBGE - Instituto Brasileiro de Geografia e Estatística. Pará » Curralinho. Disponível em: <http:/ / www.cidades.ibge.gov.br/xtras/perfil.php?lang=\&codmun=150280\&search =para $\mid$ curralinho $>$. Acesso em: 25 de mar. de 2016.

INEP - Instituto Nacional de Estudos e Pesquisas Educacionais Anísio Teixeira/IDEB, 2013. Curralinho. Disponível em: <http://ideb.inep.gov.br/>, 2013.

IPS AMAZÔNIA 2014 (Índice de Progresso Social na Amazônia brasileira). Disponível em: <http://www.ipsamazonia.org.br/publicacao> 2014.

KRAMER, Sonia. Infância, cultura contemporânea e educação contra a barbárie. In: BAZÍLIO, Luiz Cavalieri; KRAMER, Sonia. Infância, educação e direitos humanos. 4. ed. São Paulo, Cortez, 2011. p. 93-151.

LANDER, Edgardo. Ciências sociais: saberes coloniais e eurocêntricos. CLACSO, 2005. In: LANDER, Edgardo. (Org.). A colonialidade do saber: eurocentrismo e ciências sociais perspectivas latino-americanas. Disponível em: <http:/ / www.antropologias.org/rpc/files/downloads/2010/08/Edgardo-Landerorg-A-Colonialidade-do-Saber-eurocentrismo-e-ci\% C3\% AAncias-sociais-perspectivaslatinoamericanas-LIVRO.pdf>. Acesso em: 20 de fev. de 2017.

LOPES, Adrea Simone Canto. A construção da identidade da infância na Amazônia ribeirinha: Ilha de Cotijuba Belém - Pará. 2012. 209f. Tese (Doutorado) Programa de Pós-Graduação em Desenvolvimento Rural, Universidade Federal do Rio Grande do Sul, Porto Alegre, 2012.

LOUREIRO, João de Jesus Paes. Obras reunidas, v. 4. São Paulo: Escrituras Editora, 2000.

LOUREIRO, João de Jesus Paes. A conversão da semiótica: na arte e na cultura. Edição trilíngue. Belém: EDUFPA, 2007.

MALINOWSKI, Bronislaw Kasper. Argonautas do Pacífico ocidental: um relato do empreendimento e da aventura dos nativos dos arquipélagos da Nova Guiné melanésia. Tradução de Anton P. Carr e Lígia Aparecida Cardieri Mendonça. 2. ed. São Paulo: Abril Cultural, 1978.

MARCÍLIO, Maria Luiza. A criança abandonada na história de Portugal e do Brasil. In: VENANCIO, Renato Pinto (Org.). Uma história social do abandono de crianças: de Portugal ao Brasil: séculos XVIII-XX. São Paulo: Editora PUC Minas, 2010, p. 13-37.

MATTOS, Carmen Lúcia Guimarães de. Estudos etnográficos da educação: uma revisão de tendências no Brasil. In: MATTOS, Carmen Lúcia Guimarães de; CASTRO, Paula Almeida de. (Org.). Etnografia e educação: conceitos e usos. Campina Grande: EDUEPB, 2011.

MINAYO, Maria Cecília de Souza. O desafio da pesquisa social. In: DESLANDES, Suely Ferreira; GOMES, Romeu; MINAYO, Maria Cecília de Souza. (Org.). Pesquisa Social: teoria, método e criatividade. 32. ed. Petrópolis: Vozes, 2012. p. 9-29.

MORAES, Elisangela Marques; ALVES, Laura Maria Silva Araújo. A infância camponesa na Amazônia na visão de crianças de um assentamento no Pará. In: ARAÚJO, Sônia Maria da Silva; ALVES, Laura Maria Silva Araújo; BERTOLO, Sônia de Jesus Nunes. (Org.). Pesquisa e educação na Amazônia: reflexões epistemológicas e políticas. Belém: EDUEPA, 2014. p. 303-311. 
MÜLLER, Fernanda; HASSEN, Maria de Nazareth Agra. A infância pesquisada. In: Psicologia USP, São Paulo, v. 20, no 3, pp. 465-480, jul./set. 2009. Disponível em: <http:/ / www.revistas.usp.br/psicousp/issue/view/3462>Acesso em: 27 fev. 2017.

PNUD - Programa das Nações Unidas para o Desenvolvimento (2010). Ranking IDHM Municípios 2010. Disponível em: <http://pnud.org.br/atlas/ranking/Ranking-IDHMMunicipios-2010.aspx>, 2010.

PNUD - Programa das Nações Unidas para o Desenvolvimento. Relatório do Desenvolvimento Humano 2014 - Sustentar o Progresso Humano: Reduzir as Vulnerabilidades e Reforçar a Resilência, 2014. Disponível em: <http:/ / www.pnud.org.br/arquivos/RDH2014pt.pdf>

POJO, Eliana Campos; VILHENA, Maria de Nazaré. Crianças ribeirinhas da Amazônia paraense. In: SILVA, Isabel de Oliveira e; SILVA, Ana Paula Soares da; MARTINS, Aracy Alves (Orgs.). Infâncias do campo. Belo Horizonte: Autêntica editora, 2013, p. 135-148. (Coleção Caminhos da Educação no Campo)

RIBEIRO, Darcy. O povo brasileiro: a formação e o sentido do Brasil. São Paulo: Companhia das Letras, 2006.

ROSEMBERG, Fúlvia; ARTES, Amélia. O rural e o urbano na oferta de educação para crianças de até 6 anos. In: BARBOSA, Maria Carmen Silveira. et al. (Org.). Oferta e demanda de educação infantil no campo. Porto Alegre: Evangraf, 2012. p. 14-69.

ROSEMBERG, Fúlvia. Criança pequena e desigualdade social no Brasil. Disponível em: <http:/ / www.diversidadeducainfantil.org.br/PDF/CRIAN\%C3\%87A\%20PEQUENA \%20E \% 20DESIGUALDADE \% 20SOCIAL \%20NO\%20BRASIL $\% 20-$

\%20F\% C3\%BAlvia\%20Rosemberg.pdf>. Acesso em: 12 de fev. de 2017.

UFPA/ICSA/MDA/PITCPES/GPTDA. Relatório Analitico do Território do Marajó 2012. Disponível em: <http://sit.mda.gov.br/download/ra/ra129.pdf>. Acesso em: 10 de mar de 2015.

SARMENTO, Manuel Jacinto. Imaginário e culturas da infância. Disponível em: $<$ http:/ / titosena.faed.udesc.br/Arquivos/Artigos_infancia/Cultura\%20na\%20Infanci a.pdf>. Acesso em: 8 de abr. de 2017.

SILVA, Maria das Graças da. Práticas educativas ambientais, saberes e modos de vida locais. In: Revista Cocar, UEPA, v. 1, n. 1. Belém: EDUEPA, 2007. p. 47-57.

SOUSA, Emilene Leite de. Umbigos enterrados: corpo, pessoa e identidade Capuxu através da infância. 2014. 422f. Tese (Doutorado) - Programa de Pós-Graduação em Antropologia Social da Universidade Federal de Santa Catarina, Florianópolis, 2014. Disponível em: <https:/ / repositorio.ufsc.br/xmlui/bitstream/handle/123456789/130980/332919.pdf ?sequence=1\&isAllowed =y>. Acesso em: 31 de mar de 2017.

SOUZA, Alexandre Augusto Cals. Políticas educacionais na Amazônia: estado, democracia, sociedade civil e participação. Jundiaí: Paco Editorial, 2015.

recebido em: 25.09 .2017 aceito em: 30.11.2017 